\title{
Business Expansion Efforts Through Empowering Business Groups With Lee Min Book
}

\author{
Heidy Paramitha Devi ${ }^{1 *}$, Puji Nurhayati², Hapsari Endras Ayu Novita ${ }^{3}$, Mutiatun Nur Fauziah ${ }^{4}$, Cindy Violita \\ , Anisa Ayera6 \\ 1, 2, 3, 4, 5, Bussines and Economic Faculty, PGRI Madiun University, Madiun \\ *E-mail: heidypd88@gmail.com
}

Submited Article March 24, 2021

Review article Agustus 13, 2021

Accepted article Agustus 18,2021

\begin{abstract}
Cileng Village is one of the villages located in the eastern part of Alas Tuwo Village, Poncol District, Magetan Regency with an area of $6.02 \mathrm{~km}^{2}$. The livelihoods of the population include Indonesian workers, village officials, vegetable traders, farmers, farm workers, and teachers. For residents who have higher education they tend to work outside the region, so the real situation that appears there are many people who depend on the agricultural sector. Wages as farm laborers are varied, ranging from Rp. 25,000 - Rp. $45,000 /$ person/day. For one harvest period (4 months) it takes approximately 1 week of work. If on average a farm laborer earns between IDR 175,000 and IDR 315,000/person/week, this is very far from the word prosperous, so there needs to be a real movement from the PKK mobilizing team to provide alternative businesses for residents and their members. Through the Community Service (PKM) program funded by LPPM Universitas PGRI Madiun in 2019, training on recycling bottled beverage waste into women's bags was held as a program to foster an entrepreneurial spirit, whose activity targets were PKK women. Entrepreneurship ability based on creative industries in the form of bag crafts made from plastic bottle lips turned out to be effectively applied because it was able to become an alternative income for PKK members. For one bag, it costs IDR 50,000 - IDR 80,000 depending on the voring and the complexity of making. The raw material in the form of plastic bottle lips is quite easy to obtain from the waste bank in the village and from plastic waste collectors on the border of Alas Tuwo Village. Other raw materials such as voring, zippers, buttons, macrame rope, beads, and other decorations are also easy to get from several sewing equipment shops in Plaosan sub-district.
\end{abstract}

Keywords: Business Legality; Simple Bookkeeping; Group Business MarketingAbstract

\section{INTRODUCTION}

Cileng Village is one of the villages located in the eastern part of Alas Tuwo Village, Poncol District, Magetan Regency with an area of $6.02 \mathrm{~km}^{2}$. The livelihoods of the population include Indonesian workers, village officials, vegetable traders, farmers, farm workers, and teachers. For residents who have higher education they tend to work outside the region, so the real situation that appears there are many people who depend on the agricultural sector. Wages as farm laborers are varied, ranging from Rp. 25,000 - Rp. 45,000/person/day. For one harvest period (4 months) requires processing time of approximately aweek. .. If on average a farm laborer earns between IDR 175,000 and IDR 315,000/person/week it is very far from the word prosperous, so there needs to be a real movement from the PKK mobilizing team to provide alternative businesses for residents and their members. Through the Community Service (CSP) program funded by LPPM Universitas PGRI Madiun in 2019, a training on recycling bottled beverage waste into women's bags was held as a program to foster an entrepreneurial spirit, whose activity targets were PKK women..

Entrepreneurship ability based on creative industries in the form of bag crafts made from plastic bottle lips turned out to be effectively applied because it was able to become an alternative income for PKK members. For one bag, it costs IDR 50,000 - IDR 80,000 depending on the voring and the complexity of making. The 
raw material in the form of plastic bottle lips is quite easy to obtain from the waste bank in the village, and from plastic waste collectors on the border of Alas Tuwo Village. Other raw materials such as; voring and zippers. Cileng Village is one of the villages located in the eastern part of Alas Tuwo Village, Poncol District, Magetan Regency with an area of 6.02 square $\mathrm{km}$. The economic activities of the population include Indonesian workers, village officials, vegetable traders, farmers, farm workers, teachers. For residents who have higher education they tend to work outside the region, so the real situation that appears there are many people who depend on the agricultural sector for a living. Wages as farm laborers are varied, ranging from Rp. 25,000 - Rp. 45,000/person/day. For one harvest period (4 months) it takes approximately 1 week of work. If on average a farm laborer earns IDR 175,000 IDR 315,000/person/week. This is very far from the word prosperous, so there needs to be a real movement from the PKK mobilizing team to provide alternative businesses for residents and their members. So through the Community Service (PKM) program funded by LPPM PGRI Madiun University in 2019, training on recycling bottled beverage waste into women's bags was held as a program to foster an entrepreneurial spirit, whose activity targets were PKK women.

The ability to entrepreneurship based on creative industries in the form of bag crafts made from plastic bottle lips turned out to be effectively applied because it was able to become an alternative income. For one bag, it costs IDR 50,000 - IDR 80,000 depending on the voring and the complexity of making. While the raw material in the form of plastic bottle lips is quite easy to obtain apart from the waste bank in the village, also obtained from plastic waste collectors on the border of Alas Tuwo Village. Raw materials such as voring, zipper,

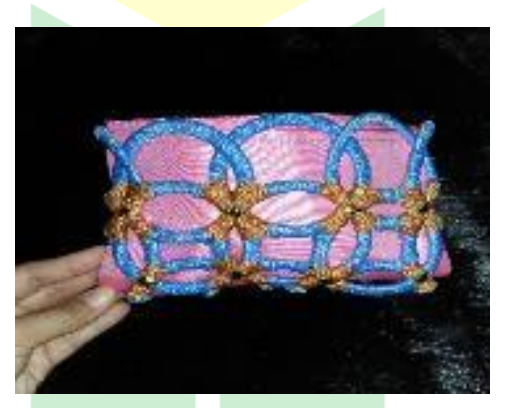

Figure 1. Recycled Bags from Plastic Cup Lips

The survey results obtained that the bag production process uses a by-order system (order based production/ production based by order), the capital for the production process uses family welfare program fresh money and there is no good recording, marketing is also limited to the surrounding community. Therefore, the group requires assistance in business management, business legality and bookkeeping through the community service program, through mentoring and development of Le Min Book (Legality, Business Management and Bookkeeping) as a form of sustainability from the empowerment program in the previous year. This activity is in line with the goals of the PKK movement, namely improving the community's economy through UP2K (Efforts to Increase Family Income), FBK (Family Based Enterprises) and reducing plastic waste, empowering independent villages, and improving the regional economy at the spearhead of regional development.

\section{COMMUNITY OVERVIEW, PROBLEMS AND PROBLEM SOLUTIONS}

\section{General description}

Cileng Village is one of the villages located in the eastern part of Alas Tuwo Village, Poncol District, Magetan Regency with an area of $6.02 \mathrm{~km}^{2}$. The livelihoods of the population include Indonesian workers, village officials, vegetable traders, farmers, farm workers, and teachers. For residents who have higher 227

Business Expansion Efforts Through Empowering Business Groups With Lee Min Book

Heidy Paramitha Devi, Puji Nurhayati, Hapsari Endras Ayu Novita, Mutiatun Nur Fauziah, Cindy Violita, Anisa 
education they tend to work outside the region, so the real situation that appears there are many people who depend on the agricultural sector. Wages as farm laborers are varied, ranging from Rp. 25,000 - Rp. $45,000 /$ person/day. For one harvest period (4 months) requires processing time of approximately aweek. .. If on average a farm laborer earns between IDR 175,000 and IDR 315,000/person/week it is very far from the word prosperous, so there needs to be a real movement from the PKK mobilizing team to provide alternative businesses for residents and their members. Through the Community Service (PKM) program funded by LPPM Universitas PGRI Madiun in 2019, a training on recycling bottled beverage waste into women's bags was held as a program to foster an entrepreneurial spirit, whose activity targets were entrpreuner group welfare women organization
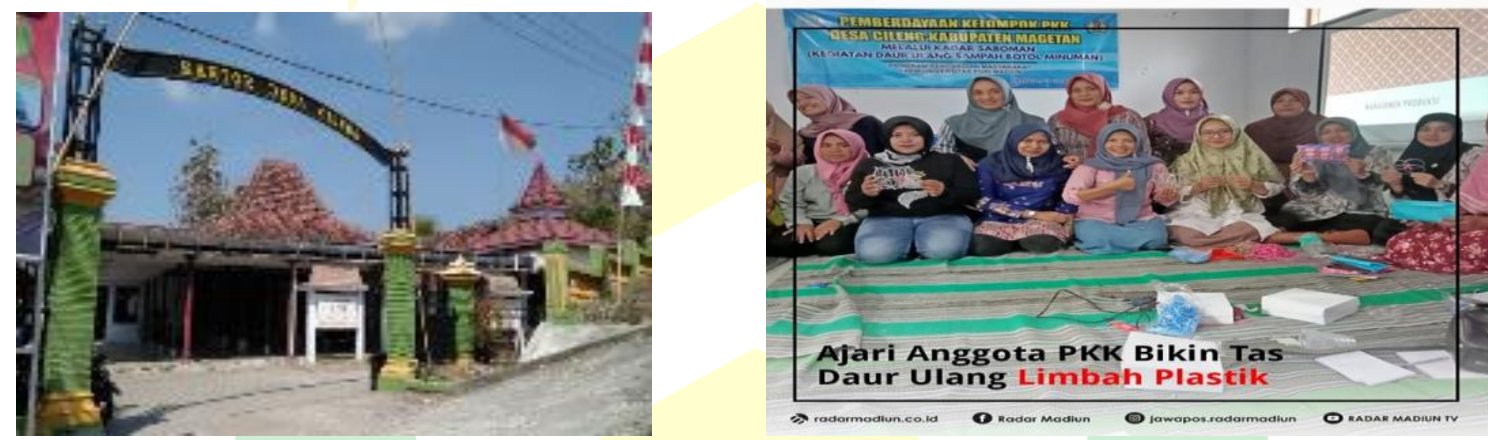

Figure 2. Abdimas Batch I Activities and Place of Implementation

\section{Problem}

The survey results found that the bag production process still uses the by-order system (production based by order ), the initial capital used for the production process uses PKK fresh money and there is no good recordkeeping, and the marketing system is also limited to the surrounding community.

Target solution

Based on the general description and problems found, it can be concluded that the creative economy activity initiated by the Cileng Village PKK group still needs assistance in business management including marketing, business legality and bookkeeping. This assistance through the program of Le Min Book (Legality, Business Management and Bookkeeping).

\section{METHOD}

The measurement in this community service is using development method through entrepreneurship training and developing business bookkeeping models and developing marketing strategies. The targets of this activity are non-economic groups, namely the PKK women's group in Cileng Village, Poncol District, Magetan Regency and some community leaders. The instrument used is a descriptive observation check list, pre and post activities. : 


\section{a. Planning}

This stage consists of activities involved team coordination, identifying criteria, planning training and mentoring, planning for program implementation evaluations as well as planning an agenda for preparing reports, submitting activity reports and planning plans for writing scientific articles in national journals.

b. Conducting Coordination Meeting

At this stage, the team conducts a team task distribution meeting, scheduling coordination meetings aimed at carrying out this activity, starting from preparation, implementation and evaluation, preparing reports and submitting reports and writing articles according to the plan that has been set.

c. Preparing PKK Partners in Cileng Village

d. The determination of partners in PKM activities involves some criteria such as: having high willingness, ability and enthusiasm, having high commitment and loyalty, being physically and mentally healthy being a PKK member who are willing to participate in the mentoring and training program from beginning to end. Training

Training is a method that is given in order to provide knowledge and certain things that are brought by a trainer (Gendro Salim, 2010). The Training Method is divided into 2 (two) parts as follows:

a) Part 1 (one) training: Creativity and innovation training is aimed at enabling partners to have creativity and innovation power. In the creativity training partners are given an overview of ways to create new ideas, training to find new ways to address problems and take advantage of business opportunities in the field of making and decorating women's bags. While in innovation training partners are trained to be able to apply new ideas, especially in designing women's bag product brands.

b) Training part 2 (two): Business management training includes business legal assistance and simple bookkeeping training.

c) Accompaniment (assistance??)

The companion (assistance) method is intended so that partners can apply or implement the results of the training approach method (Masita, E. D., Maimunah, S., \& Abidah, S. N., 2020). In this case, mentoring includes mentoring for creativity and innovation and mentoring in management. In this mentoring approach, partners are accompanied by a team and mentoring staff, which is intended so that partners can apply the results of the training with guidance and direction from mentors at partner locations, so that empowerment of the PKK group of women in Cileng Village can be achieved.

\section{RESULTS AND DISCUSSION}

1. Entrepreneurship training

This training aims to foster creativity, innovation and new ideas and take advantage of business opportunities, especially in the field of brand design, brand names and product characteristics

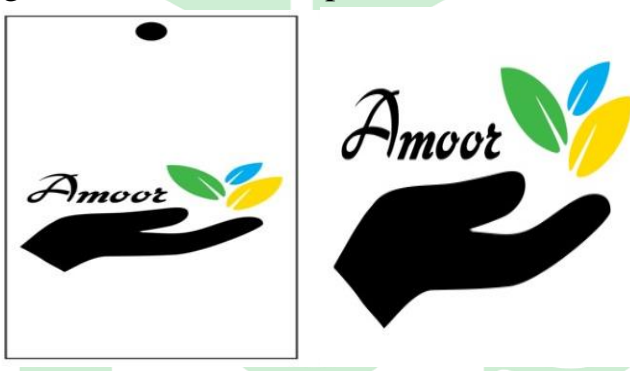

Figure 4 the results of creativity and innovation in logo design and business profiles

Logo design is adapted from the philosophy of the handcrafted brand, namely AMOOR which means blending. This logo or trademark, will be a differentiatiator between the handwork produced by partners and 
competitors. On the other hand, the PKM team also helps to register trademarks, in order to have brand legality. The meaning of the logo:

a. The hand drawing symbolizes that this product is the handmade of the women of the PKK group in Cileng Village.

b. The image of Water symbolizes life, which means this hand-processed product flows blessings.

c. The Yellow and Blue colors symbolize the relationship between partners and the UNIPMA community service team

2. Business management training which includes business legal assistance, marketing and simple bookkeeping training.

According to (Hadiyati, 2008.) marketing is the main problem faced by SMEs, namely related to marketing and product competition, access to market information and supporting institutions for small businesses.

This PKM activity is expected to be a solution to those problems, one of which is by using brands on products owned by producers, so that products can be known by consumers and ultimately can compete in the market.

This PKM partner does not yet have business legality, so it is necessary to hold socialization on the importance of this legality, and assistance in its management. Socialization is done by sharing knowledge about the legality of MSMEs. Previously, the PKM team formed an organizational management structure which later this management was used as the responsibility center for business activities. Then the licensing assistance is integrated electronically through www.oss.go.id. After obtaining the legality of the business, it is hoped that partner businesses can be more competitive in the midst of the global era, and are trusted by consumers as good and worthy products. PKK Group Craftsman Management Structure:

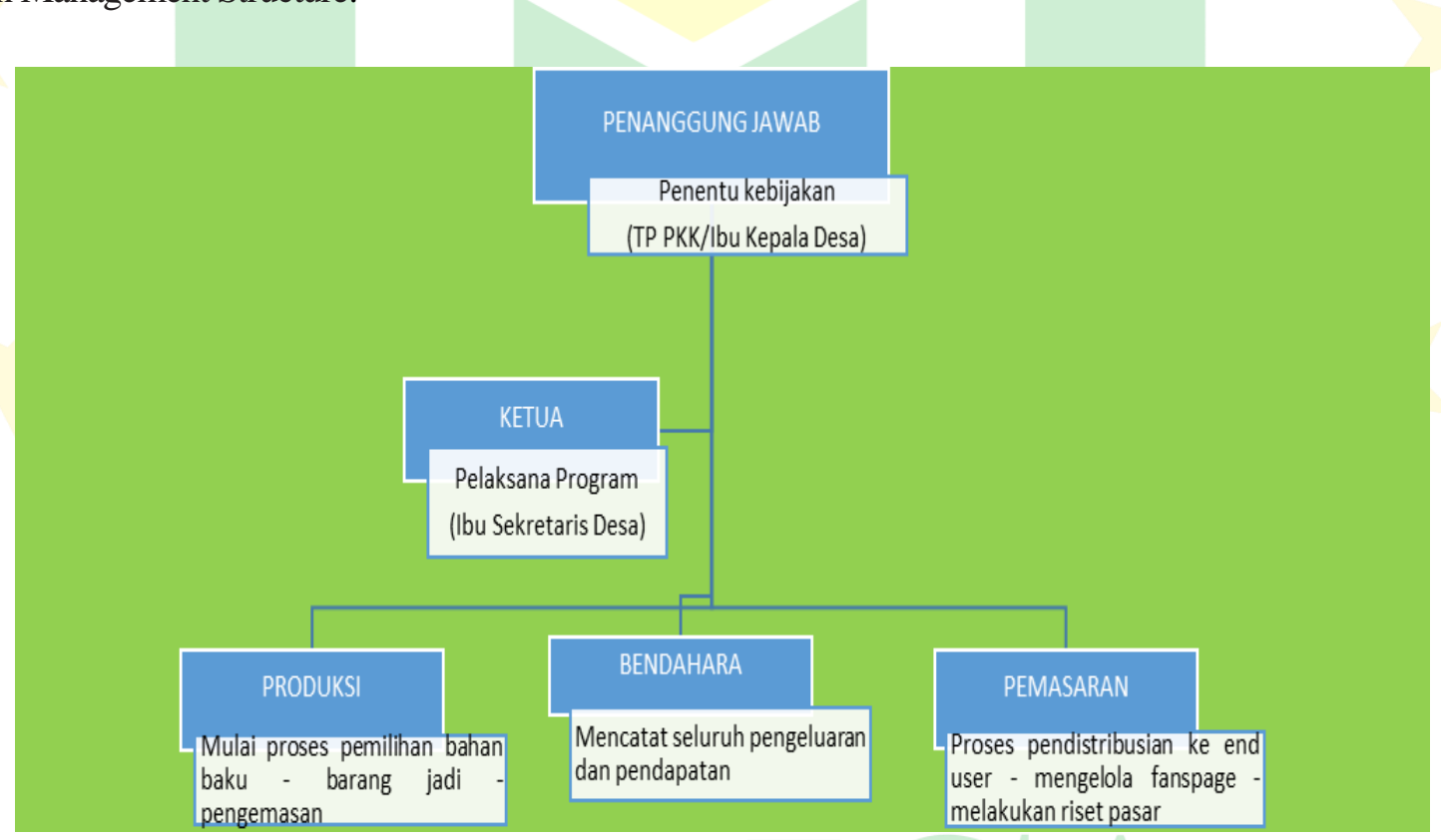

Figure 5 Management Structure

According to (Mia Ajeng, 2018) more adequate marketing training is through the introduction of e-commerce or market places and social media as a means of marketing. Meanwhile (Wijaya, 2014) states that today the number of internet users has increased significantly, thus attracting producers to use this media in marketing their products. Online marketing media makes it easier for consumers to reach producers. Prior to this activity, the partner group only relied on promotion through "getok tular". Partners are given socialization, training and assistance in marketing products offline and online. The intended online marketing is by utilizing information technology and social media applications, namely through: 1) business instagram; 2) Facebook fan page. The activities mentioned above are carried out to reach the increasing market, by marketing products through tourist 
attractions around Poncol District, as well as having the skills to market products online. Online marketing media introduced to PKM partners through training were Instagram business and social media through Facebook. To make it easier for consumers to recognize the products produced by partner groups, a name was created for the account, namely amoor_id. Through the use of more modern marketing technology, PKM partners can be more easily inform the public their products and increase network with consumers.

Partners are given education, training and assistance in implementing simple financial bookkeeping in their businesses. This training material covers the bookkeeping of financial transactions, both expenditure and income. The purpose of this training is partners have an understanding of the basic concepts of simple financial bookkeeping, so that they have neat financial statement records related to expenditure and income transactions, and finally partners can find out the profit and loss of operations in a certain period.

On the other hand, partners are also given training on how to determine the cost of goods sold and bookkeeping daily financials in a simple way.

From the results of field observations, the PKM team tried to give quizzes related to financial recording materials, from 10 participants 4 of them answered correctly. So, this can be concluded that training and assistance in simple financial bookkeeping is very beneficial for the business continuity of partner groups.

\section{CONCLUSIONS AND SUGGESTIONS}

The service activity program is able to improve entrepreneurial knowledge and skills in the aspects of creativity, product identity, marketing and business finance

\section{ACKNOWLEDGMENTS}

Profound gratitude for the blessing of Allah azza wa jala, so that this community services programe can run smoothly. A big thank you to: 1) LPPM Universitas PGRI Madiun who has supported from various aspects for the realization of this community services programe, 2) Head of Cileng Village, Poncol District, Magetan Regency and his staff who have been open to accepting the community services programe team, 3 ) Team members of community services programe and participants who have been together during the program

\section{REFERENCE}

Hadiyati, E. (2008. ). Model Pemasaran dalam pemberdayaan Usaha Kecil. Jurnal Manajemen Gajayana, $5(1)$.

Hamid, H. (2018). Manajemen Pemberdayaan Masyarakat. De La Macca: Makasar.

Hanoatubun, S. (2020). Dampak Covid-19 terhadap Perekonomian Indonesia. EduPsyCouns: Journal of Education, Psychology and Counseling, 2(1), 146-153.

Kamaruddin, M. (2020). Inovasi Metode Pembelajaran Project-Drill-Inquiry (PRODRY). DOI 10.17605/OSF.IO/Y7VWQ

M., Ma'ruf, N., Ningsih, S., and Marzuki, I. (2019). Utilization Of Durian Seed By-Product As Material Of High Nutrious Donut Based On Organoleptic Test. Prosiding Seminar Nasional Inovasi Teknologi Hasil Perkebunan, BBIHP., 1(23), 1-5.

Masita, E. D., Maimunah, S., \& Abidah, S. N. (2020). Implementasi Kawasan Zero Susu Formula dengan Kedasi (Kedai Support Asi) di Kelurahan Wonokromo Surabaya. JPM17: Jurnal Pengabdian Masyarakat, 5(01), 01-06. 
Mia Ajeng, A. (2018). Peningkatan Pendapatan Rumah Tangga Melalui Pemberdayaan Ibu-Ibu PKK di Kota Kudus. Journal of Dedicators Community, 2(2), 83-90.

Salim, G. (2014. ). Effective Coaching. Jakarta: PT. Buana Ilmu Populer.

Saputra, S. and Mulasari, S. A. (2017) 'Pengetahuan, Sikap, dan Perilaku Pengelolaan Sampah pada Karyawan di Kampus', Jurnal Kesehatan Masyarakat, 11(1), pp. 22-27.

Wijaya, M. \&. (2014). Pengaruh Rancangan Situs, Harga, Kepercayaan dan Keamanan Terhadap Pembelian Produk Fashion Melalui Online Shopping. Jurnal Manajemen Dan Pemasaran Jasa, 7(2), 31-62. 